\title{
Water Governance of Singapore in Achieving Sustainable Water Security
}

\author{
Theresia Octastefani ${ }^{1,3}$, Bayu Mitra Adhyatma Kusuma2,3 \\ ${ }^{1}$ Lecturer at Gadjah Mada University, Yogyakarta \\ ${ }^{2}$ Lecturer at Sunan Kalijaga State Islamic University, Yogyakarta \\ ${ }^{3}$ Alumni of Brawijaya University, Malang
}

\begin{abstract}
Nowadays, the supply of clean water in the world is declined because of the human population growth pressure. So that water security is a real challenge for the people in the twenty-first century. More than a third of the world's population is not fulfilled the need for clean water, both for drinking water and sanitation. Various policies through the water governance need to be done in addressing the water crisis. It is because state/government remains the locus of power in managing natural resources for development. Singapore is one of country which previously experienced major problems in the availability of fresh water. Since separation from Malaysia in 1965, water becomes a major problem. Singapore does not have a clean water source because geographically Singapore is surrounded by beaches. This research will focus on how is the water governance in Singapore can achieve sustainable water security. Furthermore, to elaborate data, this research uses qualitative method with descriptive analysis approach. The result of research shows that to overcome the water crisis problem, the governments of Singapore take steps that are very creative and innovative to manage water independently with the goal to achieve water self-sufficiency and water security. Through the Public Utilities Board (PUB) program, Singapore's government cans fulfill the water needs for the people. Singapore implemented water governance by designing a comprehensive water management strategy which consisting from the protection and expansion of its water sources, reclamation of wastewater, desalination, demand management, and public education and awareness programs. Holistic approach to water governance has allowed Singapore to achieve sustainable water self-sufficiency and water security which is one of the best examples for innovative water management in the world.
\end{abstract}

Keywords: Water Governance, Security Concept, Water Security

\section{INTRODUCTION}

Shortly after the turn of the twenty-first century, the world found itself in the midst of remarkable resource commodity boom: investment and terms of trade in extractive industries were at record levels [1]. After that the resource commodity boom eventually disrupts the resource security. And currently, we often listen the term of security. Security is very important in the human life. Security can be described as a condition of being free from danger or threat, or in other word Security is the degree of protection against danger, damage, loss, and crime. With the demise of the cold war, new concept of security that addressed not only the military realities of the contemporary world but also the

Corresponding Address:

Theresia Octastefani

Email : theresiaoctastefani@gmail.com

Address : Jl. Socio Justicia No. 2, Bulaksumur, Yogyakarta 55281 political, economic and social realities were developed [2].

Despite substantial progress in many areas, human development has been inequitable: around a seventh of the world's population does not have a secure food supply and has only limited access to clean water, sanitation or modern sources of energy. At the same time humans are over exploiting natural resources in many regions. In several areas of the world this is already quite evident. A third of the world's population lives in water-stressed countries. We have severely modified or completely replaced many terrestrial and aquatic ecosystems, and many ecosystem services are degraded [3]. Water, especially fresh water, will become one of the scarcest resource for human and societies [4].

Water is one of the essential requirements for humans. Water used for human resource sectors and needs, ranging from household, industrial, transportation, energy generation, health and other needs. 
According United Nations Environment Program or UNEP, water security represents a unifying element supplying humanity with drinking water, hygiene and sanitation, food and fish, industrial resources, energy, transportation and natural amenities, all dependent upon maintaining ecosystem health and productivity [5]. Thus we can say that the problem of water is a problem that is quite sensitive into human life.

Water security is the gossamer that links together the web of food, energy, climate, economic growth, and human security challenges that the world economy faces over the next two decades [6]. The water requirement is not only in terms of quantity but also quality. Physically clean water standards should be clear, colorless, tasteless, odorless, normal temperature and does not contain substances that are harmful to humans. Problem of shortage of water resources is exacerbated among others by population growth, urbanization, excessive water consumption, and also climate change are increasingly shrinking freshwater resources.

According United Nations of Economic and Social Affairs or UNDESA in Governance for the Millennium Development Goals, water security is an access to safe drinking water and sanitation, both of which have recently become a human right [7]. While not part of most water security definitions yet, availability of and access to water for other human and ecosystem uses is also very important from a Nexus perspective. Various places in the face of the earth, at the moment there is a shortage of water resources, resulting in loss of life and livelihoods. According to UNESCO Reports in this book "Water for People, Water for Life" stating that the problems associated with the management of water resources, there are about 25,000 peoples die each day due to malnutrition, and 6,000 other people, mostly children under five years old, died from the disease related to water [8].

Beside the world's clean water supply is decreasing due to population growth, expanding urbanization and the industrialization, water availability is also impacted by climate change. In contrast, its demand is increasing leading to the need for better water management strategies. In 2000 the United Nations (UN) pledged to decrease the proportion of the population without access to safe drinking water and basic sanitation by $50 \%$ before 2015 as part of the Millennium Development Goals [9].

The World Health Organization (WHO) estimated that approximately 884 million peoples do not have access to improved sources of drinking water and approximately 2.6 million peoples do not have adequate sanitation in 2010. Water security is a defining challenge for society in the $21^{\text {st }}$ century. Developing countries are still struggling to supply its people with clean water, but many developed countries and regions including Australia and the United States are also facing water crises. In the Middle East, the problem is not just another fight "black gold" or oil, but also has spread to the "blue gold" or water. The problem is amplified by unsustainable water management practices. Water security analysis of this kind are entirely possible without asking what kind of role water plays outside to the sphere of geopolitics, its national, regional, or local personal specificity [10].

Looking forward about the strategic value of water resource, the water governance is become very important. Various policies in the management of water resources need to be done to address the ongoing water crisis. One of the successful countries in water management is the Republic of Singapore. Singapore has no lakes, natural aquifers or groundwater and therefore has limited water sources. Due to its water scarcity, Singapore imports $40 \%$ of its water from Malaysia under an agreement signed in 1962 which secures this water supply for Singapore until 2061. The agreement ensures a low price for the water set at SGD $0.01 / 1,000$ gallons (3.78 $\mathrm{m}^{3}$ ). Negotiations are currently underway to renew the contract after it expires but Malaysia is asking for prices 15 to 20 times higher than the current price. The agreement puts Singapore in a vulnerable economic and political position and motivated the need for a more selfsufficient water supply system. Besides water supply, sanitation, storm water and waste management, water is fundamental to megacities in several other aspects too [11]. 
Since Singapore separation from Malaysia in 1965, Singapore had a major problem namely the problem of clean water. It is because Singapore always depends on the supply of clean water from Malaysia. In other hand Singapore growing through the industrial development. Industrial development is a positive effort, but in addition the construction industry has also led to a negative impact on the environment. Irresponsible industrial development can lead to several things such as the lack of clean air and water that is absolutely required by all living things [12].

The clean water crisis is universally threatening and immensely complex. Fortunately, innovative models and inclusive decision-making are offering new hope for how the Singapore Government can respond and secure to one of its most critical challenges. It is becoming a very important and vital because state remains the locus of power in managing natural resources for development, pressure from above and below are influencing the reform agenda at the national level [13]. Although is not simple to change the configuration of state-market relation and transform of resource management in the scales of governance. The axiom that good governance is the solution to the resource curse in turn informed a host initiatives specifically aimed at national-level state institution [14]. Including to maintain water security.

Based on the fact above, the research question is: How is the water governance in Singapore can achieve sustainable water security?

\section{RESEARCH METHODS}

This research is use qualitative method with descriptive analysis approach. Qualitative method is the chosen type for this research as a set of non-statistical inquiry techniques and processes used to gather data about social phenomena [15].

\section{Data Collecting Technique}

Data collecting method are the strategic step in the research. Data collection techniques used in this research is:

\section{Observation}

Observation is data collection by the object that is researching on the circumstances and the actual reality and to obtain answers to the problems. Observation has a long tradition in social science [16]. The authors do the direct observation in Singapore.

2. Related Text and Document

Document both historical and contemporary is mean to obtain or to get accurate theories and references regarding data of the result findings by studying relevant rules, regulations, reports, documents and literatures. Text and document are not only produced, but also, in turn, productive [17]. Related text or document is like act, regulation, statistic data, prior research and etc.

\section{Data Analysis Technique}

In this study, researcher use qualitative data analysis model of Miles and Huberman. Data analysis techniques of Miles and Huberman consist from four activities, namely: data collection, data reduction, data display, and conclusion [18].

1. Data Collection

The authors come to Singapore directly to collect of primary data and supported by secondary data.

2. Data Reduction After collect the data, the authors selecting the important data and reduce the other data.

3. Data Display

After selecting the important data, the authors will display the result of research with the descriptive analysis style.

4. Conclusion

After displaying the result of research, the authors make a short conclusion.

\section{RESULT AND DISCUSSION \\ Water Condition in Singapore}

Singapore is a city state with an area of about $700 \mathrm{~km}^{2}$. It currently consumes about 1.36 billion liters of water per day. It is a water-scarce country and thus imports its entitlement of water from the neighboring Johor state of Malaysia, under long-term agreements signed in 1961 and 1962, when Singapore was still a self-governing British colony. Under these agreements, Singapore can transfer water from Johor for a price of less than 1 cent per 1,000 gallons until 2011 and 2061 respectively. The water from Johor is imported through three large 
pipelines across the $2 \mathrm{~km}$ course way that separates the two countries.

In August 1965, Singapore became an independent country. The Constitution of Malaysia was stipulated that:

"The Government of Singapore shall guarantee that the Public Utilities Board of Singapore shall on and after Singapore Day abide by the terms and conditions of the Water Agreements dated $1^{\text {st }}$ September 1961 , and $29^{\text {th }}$ September 1962, entered into between the City Council of Singapore and the Government of the State of Johor. The Government of Malaysia shall guarantee that the Government of the State of Johor will on and after the Singapore Day also abide by the terms and conditions of the said two Water Agreements [19]."

The long-term water security was an important consideration for this newly independent nation. Accordingly, Singapore made a special effort to register the Separation Agreement in the United Nations Charter Secretariat Office in June 1966. The two countries have been negotiating the possible extension of the water agreement. The results thus far have not been encouraging since the two countries are still far apart in terms of their national requirements. Singapore would like to ensure its long-term water security by having a treaty which will provide it with the stipulated quantity of water well beyond 2061.

In contrast, the main Malaysian demand has been for a much higher price of water, which has varied from 15 to 20 times the present price. While Singapore has said that it has no problem to pay a higher price for the water it imports from Johor, its main concern has been how the price revision will be decided and not the concept of a higher price.

Because of this continuing stalemate, Singapore Government has developed a new plan for increasing water security and self-sufficiency during the post 2011 period, with increasingly more efficient water management, including formulation and implementation of new water-related policies, heavy investments in desalination and extensive reuse of wastewater, catchment management and other similar actions.

\section{The Water Governance of Singapore}

As a result, Singapore recently implemented a water governance plan which addresses some common water supply problems. They designed a comprehensive water management strategy consisting of the protection and expansion of its water sources, reclamation of wastewater, desalination, demand management, and public education and awareness programs. The holistic approach to water management has allowed Singapore to produce a sustainable and more self-sufficient water future which is a notable example for the best innovative of water management program in the world.

Beside through import activity, nowadays to meet their need for clean water could obtain from other catchment area (supplying $20 \%$ of the total requirement), desalination from sea water $(10 \%)$, and reclaimed water (30\%). Optimization of these three sources will be improved in order to achieve self-sufficiency in water supply in Singapore.

In the past, Singapore government is faced with the challenge to be self-sufficient in producing clean water and do not rely on imported water. To answer these challenges, Singapore Government should work hard in producing clean water for its population. Singapore Government is committed to maintaining water sources (both in terms of quantity and quality in the long term), expanding sources of water desalination, and reuse of waste water by using modern technology developments to enhance the availability of water, improve the quality of water and produces its own raw water so as to lower the cost management. Furthermore, the Singapore government formed Public Utilities Board (PUB).

Institutionally, PUB currently manages the entire water cycle of Singapore. Earlier, PUB was responsible for managing potable water, electricity, and gas. In April 1, 2001, the responsibilities for sewerage and drainage were transferred to PUB from the Ministry of the Environment. This transfer allowed PUB to develop and implement a holistic policy, which included protection 
and expansion of water sources, storm water management, desalination, demand management, community-driven programs, catchment management, outsourcing to private sector specific activities which are not within its core competence, and public education and awareness programs.

PUB has a very important role in the water management system in Singapore, for that there are 3 steps being taken, namely:

1. Stage 1: Handling Basic Conditions, during the period 1965-2000. The theme is "Tackling the Basics";

2. Stage 2: Development of water management during the period 20012006. The theme is "Water for All: Conserve, Value, Enjoy";

3. Stage 3: Beyond 2006: Integrating environmental issues with other sectors. The theme is "The Future - Integrating with the Environment and the World".

From the three steps, furthermore for ensuring water sustainability, PUB was implemented to the various programs and activities, namely:

1. Water for All. This program illustrates the efforts of Singapore Government to ensure the availability of drinking water sources. There are four different sources of water (Four National Taps), namely:

a. Local catchment, through taking of the local water resources.

b. Imported water, by purchasing water from neighboring countries.

c. NEWater, which is the reuse of reclaimed water. The use of reclaimed water is basically to complete water cycle that managed by PUB so that Singapore Government is able to develop water management in a closed cycle (closed loop). Reclaimed water used comes from processed water treatment plant effluent (waste), either domestic or industrial. As with many other developed countries, Singapore has a centralized processing system of sanitation (sewerage system). Almost all areas in Singapore (99\%) were served by waste water piping systems. Initially, the waste water is discharged directly into water bodies, such as rivers and the sea. d. Desalinated water, the sea water treatment with removes salt and minerals in the water.

2. 3P (Public-Private-People) Approaches: conserve water, value our water, and enjoy our water. These three approaches illustrate the government's efforts to raise public awareness of the importance of water conservation, so as to appreciate the value of water ownership and public awareness of the conservation efforts can be improved. In addition, by increasing the linkages between water availability with a variety of recreational activities, proving that conservation activities can be carried out in synergy with the tourism sector as well as to enhance the community's economy.

Furthermore, to maintain the availability of water in the future, then the treated water is used for two things:

1. Direct Non-Potable Use, primarily for the use of water for cooling for hospitals, commercial buildings and offices, as well as part of the industrial process. Before using NEWater, industry (such as Apple) use piped water from drinking water treatment plants. This effort is part of the Strategy Assignment (Replace Strategy) so that more water is available from water treatment used for domestic purposes. Utilization of NEWater will continue to rise, projected to reach $40 \%$ of the water demand in 2020 Singapore

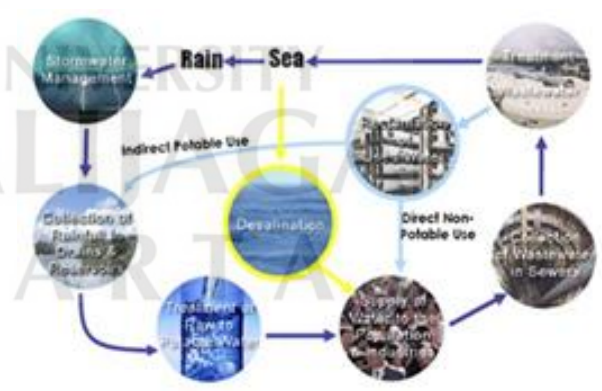

Figure 1. The Singapore Water Cycle Management [20].

2. Indirect Potable Use, i.e. by storing reclaimed water into the reservoir and then processed again to contain a variety of minerals needed by the body. Currently, only about $5 \%$ are used as raw water drinking water. However, water 
quality NEWater meets quality standard set by USEPA and WHO. Pathogen test results showed no evidence of carcinogenic effects and no long-term effects of estrogen. NEWater is a water treatment plant that can be drunk immediately. Currently there are three factories that produce NEWater in Seletar, Bedok, Kranji and Ulu Pandan. Overall production of NEWater represents more than $10 \%$ of the total requirement of water per day.

In addition, to get a more positive response from the community, the Government of Singapore using "Used Water Management" compared to "Waste Water Treatment". Used Water Management is intended to: (1) to prevent contamination and the spread of disease, (2) to protect water resources and (3) obtain alternative sources of raw water (water reclamation). The scheme of used water management can be seen in the figure below.

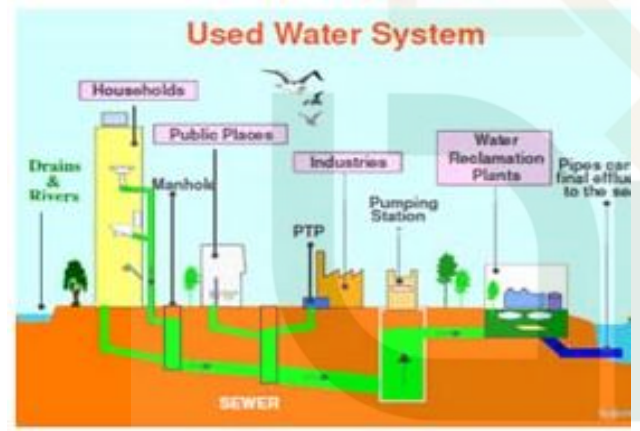

Figure 2. The Scheme of Used Water Management in Singapore [21].

Almost all areas in Singapore has been served by centralized piping system, whether from domestic (household) or from the commercial and industrial (after getting preliminary treatment/pre-treatment). To serve this need, available pipeline system, collection and treatment that is currently being developed. The Singapore Government put in place the long term Deep Tunnel Sewerage System (DTSS) to serve the entire region will only operate two centralized processing unit with an underground piping system. DTSS has many benefits, namely: more cost effectiv; free up valuable land; ensures sustainabiility of NEWater; and robust, reliable, and resilent.
DTSS phase 1 was implemented in period 2000 - 2008 and phase 2 was started in 2014 and also in progress (PUB Annual Report, 2013/2014). The picture of DTSS Phase 2 can be seen in the figure below.

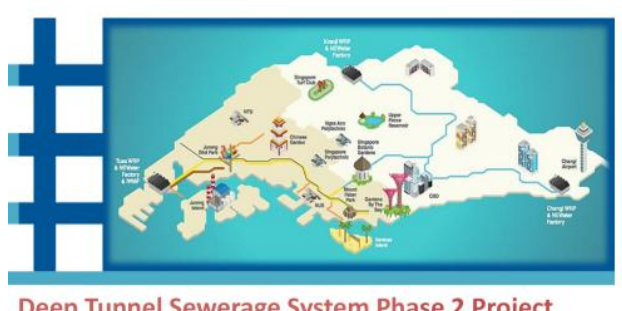

Figure 3. Deep Tunnel Sewerage System (DTSS) Phase 2 [22].

\section{The Experience of Singapore in Achieving} Water Security

It is inevitable that the various efforts made by the Government of Singapore, which is supported by the availability of resources and strong political support, has brought Singapore to be the best country in the management of drinking water in the world. To make the water management program successful in Singapore, the following are ways from Singapore government, namely by:

1. Involves the participation of various stakeholders in the development of technologies to address water and sanitation issues. The Singapore government provides award, a cash prize of SGD 300,000 and give the gold medal to those who can provide the solution to global problems by applying technology 'groundbreaking' as an effort to implement government policies and programs. In addition, the R \& D carried out in collaboration with universities, suppliers, and even the private sector.

2. Using a comprehensive manner, beginning from the establishment of tariffs that can reflect the value of water, reduce the leakage of the system, to reduce water use by consumers. At present rates of water loss in Singapore only reached $5 \%$. For the reduction of the level of water consumption, the Singaporean government made Water Conservation Programs with the theme "The 10-Litre Challenge". By running this program, there has been a decline in the 
use of 160 liters person per day in 2005 to 154 liters person per day in 2010. Expected continues to decline until 147 liters person per day in 2020.

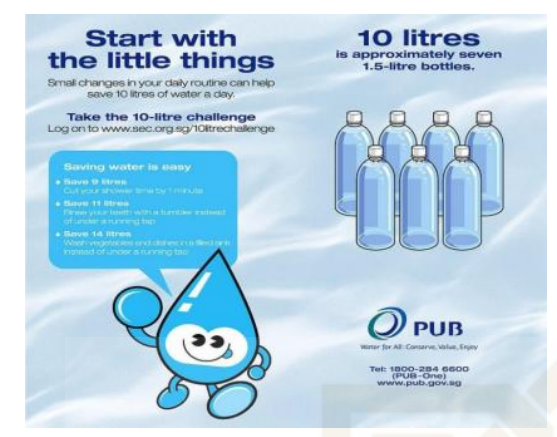

Figure 4. The 10-Litre Challenge [23].

Used Water Management Program aimed at providing an alternative water source is a very effective thing to do. When the quality of the treated water reaches the quality standard of raw process water utilization rate can be improved. The impact, drinking water is available to serve more people.

3. The development of the water industry. Water becomes a priority sector in Singapore. Not only due to the limitations of the water issue, but the government is also able to link water issues with their daily lives and even the country's economy. Various industry emerged from the water sector, such as those associated with the tourism industry-related or treatment of water technology (and-sanitation). The development of the water industry is conducted by:

a. Develop a public education to be comprehensive and visionary.

b. Build a diorama explaining the various 'traveling' developments of drinking water (and sanitation) in Singapore.

c. Promoting the use of reclaimed water for drinking water, starting from the legislative, government, artists and community leaders. This effort to prepare if in the future NEWater is the main source of drinking water in Singapore. For that promotion is an appropriate communication strategy to introduce a program created by the government along with the PUB, which the campaign is conducted by:

1) Using a branding program that easily recognized and arrested people, such as the $A B C$ Water Program, consisting of:

a) Active, through: Provide new land for public, bringing the community on issues related to water and water availability and develop a sense of ownership of the water.

b) Beautiful, through: Integrating reservoir and water flow paths with the urban landscape, make efforts over flood mitigation and water storage and creating the lifestyle and attractions of interest related to the water

c) Clean, through: Improve water quality, conduct public education and establish the relationship between people and water.

2) The use of words to branding in a variety of communication media, such as: "used water" vs "waste water"; "NEWater" vs "reclaimed water"; dan "water reclamation" vs "sewage treatment".

The success achieved by Singapore in managing water is determined by the following, namely:

1. There is strong government commitment and the support of politicians making a clear policy direction so that the program can run well and gain success.

2. The involvement of various parties, not only within the scope of the ministry, and even academia, private sector and other parties, including the media. Involvement of various stakeholders is indispensable, not only during the planning, but also during implementation.

3. The driving factor that triggered the planning and implementation of water to overcome the limited availability of water sources for drinking water.

4. The consistency of the program is very visible from all sides. Implementation of the program is not only done by the 
government, but also supported by the community.

5. The awareness of the public. Where people not only act as an object but as a subject in water management. So when the government adopted a program, people want to participate actively. To increase awareness and participation, not just focused on the promotion but also in planning the scope of activities that

6. Can be done by the community. Thus, promotional efforts are not only limited to the provision of knowledge but also provide clear direction to the activities that can be made public.

From this way, Singapore can be success in manage water supplies, finding new sources of water and sewage systems to organize an integrated and holistic manner. Nowadays, Singapore is the best country in manage an integrated water management system. Where PUB managed to diversify its water needs in Singapore and minimize the amount of water lost before the water reaches the consumer (non-revenue water). Water governance in Singapore is one of the best in the world.

One key to the success of Singapore is an integrated approach that combines analysis of supply and demand.

1. From the supply side. Singapore has what is referred to as the Four National Water Strategy or "Four National Taps" which identifies four main sources of water for development, namely: local catchment, imported water, NEWater and desalinated water.

2. From the demand side. Singapore applying progressive rates depends on the level of water consumption. Singapore also set a water conservation tax, standard installation of water for households and conducts educational campaigns and the efficient use of water.

The water price is calculated based on the cost to produce and supply them, as well as to anticipate the scarcity of water in the country and the cost to resolve them. With the charge corresponding to the costs above, Singapore is able to finance research and development and to build a new facility more innovative and efficient in order to meet water needs in the future.
Another key to success is the effectiveness of the government, a strong political commitment, clarity of rules and laws, as well as a diligent worker and experienced. All of efforts bring positive results. Water consumption per capita Singapore fell gradually from the highest level in the history of the 175 liters/day in 1994 to 156 liters/day in 2008. In 2030, PUB target water consumption per capita Singapore can reach 140 liters/day. And now, Singapore Government with PUB has dared to set a target and predicted that in 2061, Singapore is able to stop its dependence on imported water from Malaysia. Singapore seriousness in managing water supply and drinking water does not mess around.

Every year, in the last four years, they also hold the Singapore International Water Week (SIWW) which was attended by thousands of people from more than 100 countries. For Singapore, "every drop of water is precious so the water must be treated with prudence." So, the country is now fully severed to collect all wastewater, and has constructed separate drainage and sewerage systems to facilitate wastewater reuse on an extensive scale.

\section{CONCLUSION AND RECOMMENDATION \\ Conclusion}

Water is an irreplaceable element in human life. Water used for human resource sectors and needs, ranging from household, industry, transportation, energy generation, health and other needs. Water security was always pursued by each country to ensure the prosperity of its people. Since Singapore separation from Malaysia in 1965, Singapore had a major problem, namely the problem of clean water crisis because before separate from Malaysia, Singapore always depends on the supply of clean water from Malaysia.

To reduce dependence on imported water supplies from Malaysia, the Singapore government is very innovative to take steps in managing water independently with the goal to achieve self-sufficiency and water security. Through the Public Utilities Board (PUB), nowadays the Singapore government is able to meet the water needs of people. With the good management and also participation active 
that is owned by the government, PUB, and society make water governance in Singapore can be implemented well and increasingly integrated.

Currently, Singapore has managed to achieve success in water governance. Water governance in Singapore is one of the best in the world. This innovation can be adopted by developed and developing countries to improve their water management systems. If the MDGs that relate to water are to be reached, Singapore can serve as an example for developed countries/developing countries to improve their water governance.

\section{Recommendation}

Based on the above conclusions, the recommendations can be given the authors is as follows:

1. Countries that have a water source should preserve the water source, to water security and water needs of the population can be met.

2. In order to remain able to maintain water security and self-sufficiency of water for future generations, then the government, PUB, and the public should maintain a spirit of cooperation and commitment to be able to maintain water resistance.

3. Besides the use of water must also be precise and efficient. Because every drop of water has a very important meaning in life.

4. To support it all, then it should also be improved water governance to be more integrated and be the best to meet people's basic needs.

\section{ACKNOWLEDGEMENT}

The authors would like to thank the civitas academica in the Faculty of Social and Political Science Gadjah Mada University Yogyakarta, Faculty of Dakwah and Communication Sunan Kalijaga State Islamic University Yogyakarta, Faculty of Administrative Science Brawijaya University Malang, and Faculty of Political Science and Law Burapha University Chonburi Thailand, especially Dr. Suphanee Navakul, DPA for all the help and support which given to the authors.

\section{REFERENCES}

[1] Singh, JN. and Bourgouin, F. (2013). Resource Governance and Developmental States in the Global Growth: Critical International Political Economy Perspective. New York: Palgrave Macmillan.

[2] Snyder, CA. (2008). Contemporary Security and Strategy. Second Edition. New York: Palgrave Macmillan.

[3] Stockholm Environment Institute. (2011). Understanding the Nexus: The Water, Energy, and Food security Nexus. Background Paper for the Bonn 2011 Nexus Conference.

[4] Edelenbos, J. and Teisman, G. (2010). Symposium on Water Governance: Water Governance as a Government's Action between the Reality of Fragmentation and the Need for Integration. London: Sage Publication.

[5] United Nations Environment Program (UNEP). (2010). Sick Water: The Central Role of Wastewater Management in Sustainable Development. New York: United Nations Publication.

[6] World Economy Forum Water Initiative. (2011). Water Security: The WaterFood - Energy - Climate Nexus. Washington: Island Press.

[7] United Nations of Economic and Social Affairs (UNDESA). (2007). Governance for the Millennium Development Goals. New York: United Nations Publication.

[8] United Nation Education Scientific and Cultural Organization (UNESCO). (2003). Water for People, Water for Life. Retrieved on July 14, 2013 from www.unesco.org

[9] United Nations Deputy SecretaryGeneral. (2013). The Millennium Development Goals Report 2013, New York: United Nations.

[10] Burgess, JP. (2008). Non-Military Security Challenges. In Snyder, CA. Contemporary Security and Strategy. Second Edition. New York: Palgrave Macmillan.

[11] Varis, O. et al. (2006). Megacities and Water Management. International Journal of Water Resources Development Vol. 22, No. 2.

[12] Kusuma, BMA. (2014). The Role of Government in Overcoming Industrial Development Impact towards 
Environmental Sustainability. Jurnal Pembangunan dan Alam Lestari Vol. 5, No. 1.

[13] Singh, JN. and Bourgouin, F. (2013). Resource Governance and Developmental States in the Global Growth: Critical International Political Economy Perspective. New York: Palgrave Macmillan.

[14] Bourguoin, F. and Haarstad, H. (2013). From 'Good Governance' to the Contextual Politics of Extractive Regime Change. In Singh, JN. and Bourguoin, F. Resource Governance and Developmental States in the Global Growth: Critical International Political Economy Perspective. New York: Palgrave Macmillan.

[15] McNabb, N. et al. (2005). Qualitative Research Methods: A Data Collector's Field Guide. Washington: Family Health International.

[16] Punch, KF. (2004). Introduction to Social Research: Qualitative and Quantitative Approach. 2nd ed. London: Sage Publication.

[17] Prior, L. (2010). Using Documents in Social Research. In Silverman, David. Qualitative Research. 3rd ed. London: Sage Publication.

[18] Miles, MB. and Hubberman AM. (1994). Qualitative Data Analysis: A Sourcebook of a New Method. London: Sage Publication.

[19] Malaysia. Act of Parliament No. 53 of 1965. Constitution of Malaysia (Singapore Amendment) Act, 1965: An Act to amend the Constitution of Malaysia and the Malaysia Act. August 9, 1965.

[20] Hin, YW. (2015). Overview of Singapore's Deep Tunnel Sewerage System. Singapore: PUB. Retrieved on August 14, 2015 from www.pub.gov.sg.

[21] Listyasari, M. (2012). Belajar Mengelola Air Buangan dari Singapura. In Magazine of Percik: Media Informasi Air Minum dan Sanitasi. Edition of 04/2012, 10th Year. December 2012.

[22] Hin, YW. (2015). Overview of Singapore's Deep Tunnel Sewerage System. Singapore: PUB. Retrieved on August 14, 2015 from www.pub.gov.sg.

[23] Public Utilities Board (PUB). (2014). Take the 10-litre challenge. Retrieved on August 14, 2015 from

www.sec.org.sg. 